\title{
Analiza latinskih posuđenica u Etimološkom rječniku novogrčkog jezika Nikolaosa Andriotisa
}

\author{
Alka Lončar \\ Sveučilište Tri u Rimu \\ alk.loncar@stud.uniroma3.it
}

SAŽETAK: Poznato je da su grčki jezik i kultura imali velik utjecaj na rimsku kulturu i književnost na latinskom jeziku. Nešto rjeđe pozornost privlači utjecaj latinskoga jezika na grčki, osobito kada se radi o posuđenicama. Cilj je ovoga rada prikazati poteškoće te neke neutemeljene navode pri analizi latinizama zapažene tijekom istraživanja provedenoga na Etimološkom rječniku novogrčkog jezika jezikoslovca i leksikografa Nikolaosa Andriotisa.

Ključne riječi: etimologija; jezični dodir; jezično posuđivanje; latinski jezik; novogrčki jezik

\section{Uvod}

Tema ovoga rada proizišla je iz diplomskoga rada Latinske posuđenice u novogrčkom jeziku (Lončar 2020). U radu je iznesen pregled latinizama koji su tijekom različitih razdoblja grčke književnosti pronašli svoj put do novogrčkoga jezika. Polazeći od tvrdnje da su ove dvije kulture i književnosti međusobno utjecale jedna na drugu u razmjerima u kojima su rijetke druge to činile, bilo bi logično zaključiti da se taj odnos preslikavao i u jezičnom posuđivanju. Ta je tvrdnja djelomično točna, odnosno točna je kad se promatra utjecaj grčkoga na latinski jezik i rimsku kulturu. No, nije jednostavno objasniti što se točno događalo kada se situacija promatra sa suprotnoga gledišta. Tim više što je nezahvalno donositi zaključke ukoliko se utjecaj ne promotri dijakronijski, odnosno ako se točno ne odrede razdoblja.

Grčki se jezik prema Babiniotisu (2002: 18) dijeli na četiri glavna razdoblja:

1. arhajski grčki (1400. pr. Kr. - 300. pr. Kr.)

2. helenistički grčki (300. pr. Kr. - VI. st.)

3. srednjovjekovni grčki (VI. st. - XVIII. st.)

4. novogrčki (XIX. st. - danas). ${ }^{1}$

1 Za drugu popularnu periodizaciju vidi Horrocks (2010). 
Usto valja imati na umu da se u Grčkoj pitanje nacionalnoga jezičnoga identiteta nije u potpunosti riješilo sve do druge polovice XX. st. Naime, postojala je svojevrsna dvojezičnost u pismu zbog uporabe dviju varijanti istoga jezika: katarevuse i dimotikija. Katarevusa je učeni, pisani grčki jezik, u kojem se miješaju antički pravopis i moderan izgovor, a njezini su pobornici težili jezičnom purizmu, vodeći se idealom grčke antike. Dimotiki se pak smatrao jezikom naroda te su njegovi zagovornici vjerovali da pučki, razgovorni jezik vjernije oslikava prirodan jezični razvoj grčkoga još od antike (Mackridge 2009: 184-185). Godine 1976. ukida se katarevusa te dimotiki postaje nacionalni jezik. Ta dva suparnička pokreta uvelike su utjecala na oblikovanje suvremenoga grčkoga jezika i njegova leksika. Tijekom XIX. st. puristički nastrojeni pristaše katarevuse tako su na primjer mnoge strane riječi iz grčkoga rječnika izbacili i zamijenili ih antičkim grčkim riječima, uglavnom u novim značenjima, ili novotvorenicama nastalim sastavljanjem starogrčkih morfema. Primjerice,

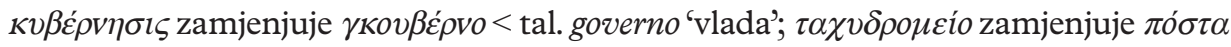

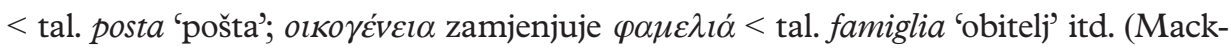
ridge 2009: 183; 2014: 152). Usprkos tomu, velik broj latinizama ostaje i pronalazi svoj put do suvremenoga grčkoga jezika, među njima i mnoge riječi koje se koriste u svakodnevnom govoru: ${ }^{2}$

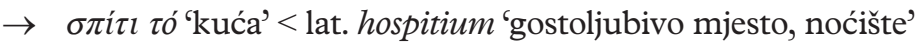

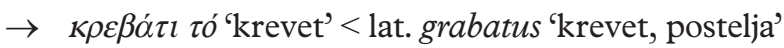

$\rightarrow \pi \delta ́ \rho \tau \alpha \dot{\eta}$ 'vrata'< lat. porta 'vrata'.

Prema Kahane (1982: 132), Viscidi je u svojem djelu I prestiti latini nel greco antico e bizantino izračunao da od ukupno 2900 latinizama u grčkome jeziku, uključujući i izvedenice, njih 300 preživljava do novogrčkoga. Međutim, jasno je da ne možemo znati koliko je točno latinizama u novogrčkom jeziku, a teško je i dati preciznu pretpostavku; djelomično zbog nedostatka sveobuhvatnih i pouzdanih izvora, a djelomično zbog toga što se nastavljaju otkrivati novi izvori (Filos 2013: 3).

\section{Rječnik u kontekstu grčke leksikografije}

Rasprava oko jezičnog pitanja u Grčkoj nepovoljno je utjecala na razvoj različitih jezikoslovnih disciplina, pa tako i leksikografije. Sukladno ranoj leksikografskoj praksi u Europi, prvi su rječnici novogrčkoga jezika dvojezične naravi s fokusom na pruža-

2 U navođenju grčkih riječi korišten je politonijski naglasni sustav, budući da je takav Andriotis koristio u svojem Rječniku, a koji je svojstven katarevusi. On je međutim ukinut 1982. godine te se od tada koristi monotonijski naglasni sustav. 
nju antičkih grčkih ili latinskih istoznačnica (Lavidas 2018: 59)3. Ako izuzmemo Etimološki rječnik arumunjskog, tj. vlaškoga jezika K. Nikolaidisa iz 1909. godine, u grčkome jeziku nije postojao etimološki rječnik sve do prvoga izdanja Andriotisova Rječnika 1951. godine. U mnogima se, među ostalim, nudi etimologija mnogobrojnih riječi, no isključivo etimološkoga rječnika grčkoga jezika nije bilo (Perakis 1994: 263). ${ }^{4}$

Sam Andriotis (1983: 1) u predgovoru prvome izdanju svojega rječnika bilježi kako je zadatak autora prvoga etimološkog rječnika iz nekoliko razloga veoma zamršen. Prvo, iz razloga što mnogim riječima novogrčkoga leksika do sada uopće nije ponuđena etimologija. Kao drugo, mnogim riječima čijom su se etimologijom istraživači bavili još uvijek nije ponuđen uvjerljiv zaključak o podrijetlu te je pitanje etimologije tih riječi i dalje otvoreno. Nadalje, mnogim je riječima ponuđeno dvije, tri ili više mogućih pretpostavki podrijetla koje će u budućnosti ili biti prihvaćene neutemeljeno, ili će jedna od njih biti prihvaćena, no u datom trenutku ne možemo znati koja. Naposljetku, Andriotis napominje kako autor jednoga etimološkoga rječnika ne može biti toliko mudar da sam ponudi etimologiju svim riječima čije je podrijetlo nepoznato, niti da sa sigurnošću prosudi je li etimologija koju je netko drugi ponudio potpuno točna ili ne, niti može prosuditi je li jedno od mnogih ponuđenih istraživanja točnije od drugih.

Neki su jezičari zamjerali Andriotisu što nije uključio velik broj standardnih riječi u svoj rječnik. Georgakas (1958: 48) primjerice bilježi da u leksikonu nedostaje više od 700 riječi koje bi u njemu trebale biti uključene te otprilike 150 riječi koje prema njegovoj prosudbi ne pripadaju rječniku standardnoga novogrčkoga jezika. Autor je određene kritike prihvatio u izdanjima iz 1967. i 1983. godine tako što je mnogo natuknica izmijenio, nadopunio ili uklonio, a neke druge uključio. Zanimljivo je vidjeti kako se količina natuknica mijenjala u trima različitim izdanjima: prvo izdanje iz 1951. sadržava otprilike 13000 natuknica, drugo izdanje iz 1967. oko 21000 natuknica (Perakis 1994: 267), a posljednje izdanje iz 1983. godine sadržava otprilike 25000 rječničkih natuknica.

3 Prvim rječnikom novogrčkoga jezika smatra se Glossarium Graeco-Barbarum Johannesa van Meursa iz 1610. godine. U njemu se nude objašnjenja natuknica kako na latinskom tako i na grčkom je-

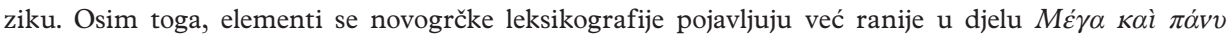

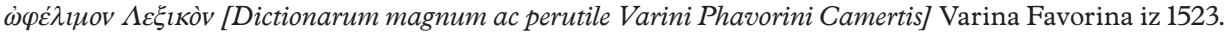

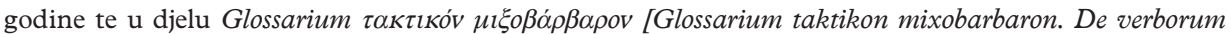
significatione, quae ad novellas imperatorum qui in Oriente post Iustinianum regnaverunt, de re militari constitutiones pertinent] Nicolasa Rigaulta iz 1601. godine.

4 Danas se među referentne etimološke rječnike novogrčkoga ubrajaju Etimološki rječnik novogrčkog jezika Giorgosa Babiniotisa (2009) te Rječnik općeg novogrčkog jezika (1998) u izdanju zaklade Manolis Triandafilidis Instituta za novogrčke studije Aristotelova sveučilišta u Solunu koji, unatoč činjenici da je opći rječnik, nudi detaljne etimološke informacije riječima stranoga podrijetla. 


\section{Jezični dodir između latinskoga i grčkoga jezika}

Jezični dodir javlja se prilikom susreta govornika dvaju jezika. Ta je pojava prepoznata još u antičko doba, a zabilježena je primjerice već u Odiseji kada Odisej govori Penelopi o izmiješanim jezicima Krete (Adams, Janse i Swain 2002: 343):

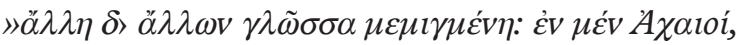

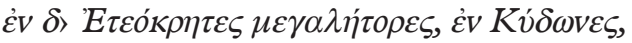

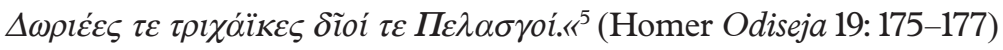

Od rimskih pisaca spomenut ćemo Horacija, koji primjećuje dvojezičnost (Canusini more bilinguis, Hor. Sat.1.10.30) ${ }^{6}$. Ona je neizbježan rezultat jezičnoga dodira čiji stupanj razvoja ovisi o učestalosti i duljini jezičnoga dodira (Adams, Janse i Swain 2002: 332). Grčki i latinski jezik članovi su jedne od najranije otkrivenih, najvećih i najbolje istraženih jezičnih porodica, indoeuropske. Članovi svake jezične porodice pokazuju mnogobrojne sličnosti i podudarnosti, a neke od njih mogu biti temelj za svrstavanje određenih članova jezične porodice u zajedničke grane. Grčka grana indoeuropske skupine treća je najranije posvjedočena, s tekstovima pisanima na linearu B koji se pojavljuju već u XIV. st. pr. Kr., a obimno je posvjedočena na alfabetskom pismu od VIII. st. pr. Kr. nadalje (Clackson, Horrocks 2011: 3). U VIII. st. pr. Kr. grčki su kolonizatori zauzeli Siciliju i gotovo cijeli južni dio Italije, naročito obalne dijelove. To geografsko područje, poznato i kao Velika Grčka, ostalo je grčko po govoru sve do kasnih vremena. Tamošnji oblik grčkoga jezika, pod imenom Grecanico, razlikuje se od novogrčkoga po mnogočemu, ali se njihovi govornici mogu sporazumjeti bez većih poteškoća. Grecanico se direktno nastavlja na koine te i danas održava neizvjesno postojanje u južnoj Italiji, točnije u Kalabriji (Sihler 1995: 13). Tako možemo zaključiti da je grčki jedini jezik osim latinskoga i iz njega proizišloga talijanskoga jezika koji na Apeninskom poluotoku preživljava sve do modernoga doba, unatoč činjenici da su poluotok nekoć nastanjivali govornici mnogobrojnih i raznovrsnih jezika. Zanimljivo je također spomenuti kako se grčki, poput albanskoga i armenskoga, nije razvio u druge jezike, za razliku od latinskoga, iz kojega su se razvili današnji romanski jezici. Pisani dokazi grčke prisutnosti u Rimu i okolici potječu iz

5 'Jezici različni tu se isprepleću, tu su Ahejci,

Eteokréćani tu su junačine, tu i Kidónci,

Dorani, kojih su plëmena tri, i dîvnī Pelàzgi.' (prijevod Tome Maretića 1987., str. 229).

6 'Po običaju dvojezičnog Kanuzijanina.' Kanuzij, jedan od najstarijih i najvažnijih gradova u Apuliji, bio je pod velikim utjecajem helenske civilizacije. Mnoštvu oslikanih vaza i kovanica pronađenih u blizini Kanuzija neosporivo je grčko podrijetlo, a vjeruje se da je grčki ondje bio glavni jezik u govoru sve do rimskoga osvajanja.

7 Drugi naziv za srednjovjekovni, tj. helenistički grčki, $\dot{\eta}$ kovví $\delta l \alpha \dot{\lambda} \varepsilon \kappa \tau$ ' 'zajedničko narječje’. 
VIII. st. pr. Kr., a najstariji natpis pronađen u Italiji i jedan od najstarijih zapisa uopće pronađen na grčkome alfabetu sastoji se od jedne riječi, eulin, koja se tumači kao eúlinos 'kolovrat'. Taj natpis urezan je na vrču pronađenom u ženskoj grobnici u naselju Osteria dell' Osa, udaljenom 20 km od Rima, a potječe iz 770. pr. Kr. Grčki su zapisi također pronađeni u Rimu, Laciju i južnoj Etruriji te se zaključuje da su vjerojatno postojale zajednice grčkih trgovaca u lučkim mjestima jer znamo da su bile prisutne u Graviski i u Pirgu u južnoj Etruriji, a i drugdje (Clackson, Horrocks 2011: 38-39). Tako je grčki jezik na ovaj ili onaj način prisutan u latinskoj književnosti od njezina začetka. Prva književna djela na latinskom jeziku zapravo su prijevodi grčkih djela, a većina je žanrova također preuzeta iz grčke književnosti, osim satire, koja je u potpunosti rimska (Clackson, Horrocks 2011: 102-103). Shodno tomu, nije iznenađujuće što je latinski jezik prepun grecizama te je utjecaj grčkoga na latinski vrlo dobro znanstveno istražen. Međutim, što se latinizama u grčkome jeziku tiče, ne nudi se velik broj radova. Postoji određen broj djela o latinskom jeziku u ranijim razdobljima grčkoga jezika, tj. u antičkom, helenističkom i srednjovjekovnom grčkom, no latinizmi u novogrčkome do sada nisu privukli znatniju pozornost istraživača.

\section{Metodologija istraživanja}

Tijekom istraživanja provedenoga na Andriotisovu Rječniku pronađeno je 638 riječi koje su iz latinskoga ušle u novogrčki, no u navedenu su brojku uključene sve riječi koje su uza sebe imale oznaku lat. ${ }^{8}$ Međutim, nisu sve riječi s oznakom lat. uzete u obzir jer su neke od njih bile stranoga podrijetla te su u latinski ušle iz nekoga drugog jezika:

$\rightarrow \quad \ddot{\alpha} \lambda \gamma \varepsilon \beta \rho \alpha \dot{\eta}$ 'algebra' < lat. algebra < arap. al-djabar

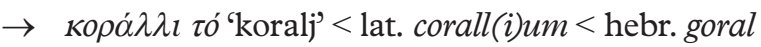

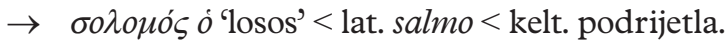

Osim toga, izostavljene su posuđenice koje su iz latinskoga u novogrčki jezik ušle posredstvom drugih stranih jezika. Ti su jezici najčešće bili talijanski, venecijanski, francuski i ostali romanski jezici, a ponekad i slavenski, germanski i dr.:

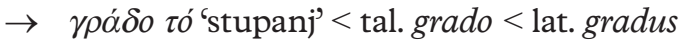

$\rightarrow \quad$ iv $\tau \rho \imath \gamma \kappa \alpha \dot{\eta}$ 'intriga' < španj. intriga < lat. intricare

$\rightarrow \kappa \alpha \beta \alpha \lambda$ lé $\rho \circ \varsigma \dot{o}$ 'konjanik, vitez' < venec. cavalier $<$ lat. caballus

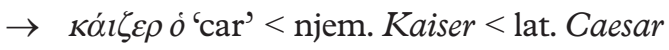

8 Naposljetku je analizirano sveukupno 406 riječi, od čega 330 izravnih te 76 povratnih posuđenica. 


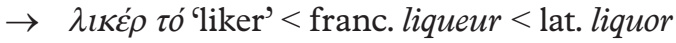

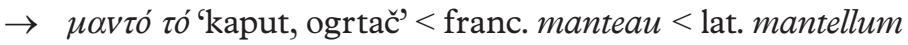

$\rightarrow \tau \sigma \dot{\alpha} \rho o \varsigma \dot{o}$ 'car' $<$ slav. tsar $<$ lat. Caesar

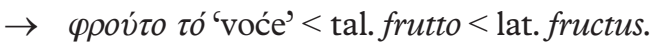

S druge strane, uvrštene su sve riječi koje su izvorno starogrčke, pri čemu su neke od njih do novogrčkoga stigle posredstvom latinskoga ili latinskoga i još nekoga stranoga jezika, tzv. povratne posuđenice:

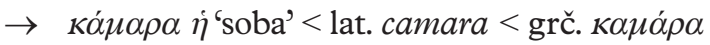

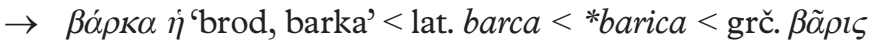

$\rightarrow \mu \pi \alpha ́ v l o ~ \tau o ́ ~ ' k u p a o n i c a$, kupka' < tal. bagno < lat. balneum < grč. $\beta \alpha \lambda \alpha v \varepsilon \tilde{c} o v$.

Najviše je pronađeno izravnih posuđenica, riječi koje su podrijetlom latinske te su u novogrčki ušle izravnim putem:

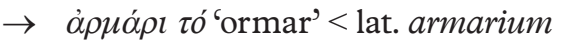

$\rightarrow \delta \eta v o ́$ olo tó 'dinar' < lat. denarius

$\rightarrow \sigma \kappa \alpha \dot{\lambda} \alpha \dot{\eta}$ 'stube, ljestve'< lat. scala

$\rightarrow \tau \alpha \beta \varepsilon ́ p v \alpha \dot{\eta}$ 'gostionica' < lat. taberna.

Nadalje, kod nekih primjera Andriotis navodi više pretpostavki za moguće podrijetlo. Neke od njih navedene su u nastavku, no nisu bile uključene u ukupnu brojku. ${ }^{9}$

$\rightarrow$ Вері́коко тó 'marelica' < lat. praecox ili arap. berkuk

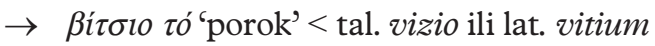

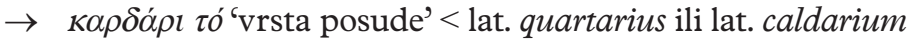

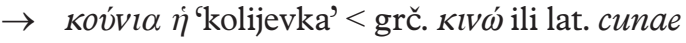

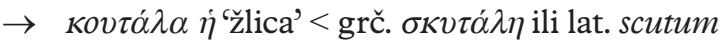

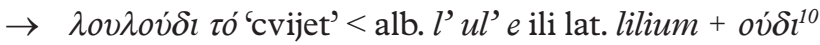

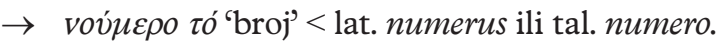

9 Za okvire diplomskoga rada nije se ulazilo u raspravu o tome koja je pretpostavka vjerojatnija od druge.

10 Grčki sufiks za deminutivne oblike imenica u srednjem rodu. 
Također, neki se primjeri kod Andriotisa pojavljuju dvaput zbog različitih oblika, no brojao se samo jedan od njih:

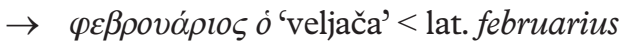

$\rightarrow \varphi \lambda \varepsilon \beta \dot{\alpha} \rho \eta \varsigma \dot{\delta}$ 'veljača' < lat. februarius.

\section{Analiza natuknica vezanih uz latinski jezik iz Andriotisova Rječnika ${ }^{11}$}

Nakon ovog pregleda dolazimo do glavnoga dijela, a to su problemi zapaženi u analizi natuknica vezanih uz latinski jezik:12

1. Andriotis ponekad ne navodi jezik posrednik, iako riječ nije posuđena izravno iz latinskoga:

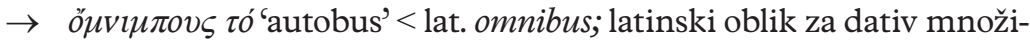
ne pridjeva sav, svaki, no riječ je prvi put posvjedočena u francuskom jeziku: voiture omnibus (Jacques Lafitte u Parizu 1819. ili 1820.) ${ }^{13}$

$\rightarrow \rho \varepsilon \alpha \lambda \imath \sigma \mu o ́ \varsigma$ ó 'realizam' < lat. realismus; radi se o stranoj složenici prema franc. réalisme ili njem. Realismus ${ }^{14}$ (od kasnolatinskoga pridjeva realis 'stvaran')

$\rightarrow \mu \alpha \tau \varepsilon \rho \alpha \lambda \imath \sigma \mu o ́ \varsigma$ ' 'materijalizam' < lat. materialismus; prema franc. matérialisme ${ }^{15}$, najbliži latinski oblik: materialis 'koji pripada stvari' (od imenice materia 'tvar, materija')

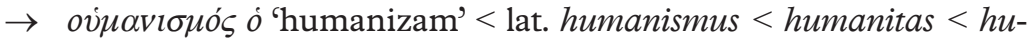
manus; 'ljudski', iako je latinski korijen riječi neosporan, sam termin prvi se put pojavljuje u tekstovima učenjaka u Njemačkoj u XIX. st. ${ }^{16}$

Kod određenih pojmova koji završavaju na »-izam« Andriotis ipak navodi posrednički jezik, što pokazuje nedosljednost:

${ }^{11}$ Za traženje potvrda konzultirana je internetska stranica Logeion, u kojoj su inkorporirani brojni rječnici latinskoga te grčkoga jezika iz različitih razdoblja, Latinsko-hrvatski rječnik Mirka Divkovića te Grčko-hrvatski rječnik Stjepana Senca.

12 Autoričin komentar slijedi iza interpunkcijskoga znaka točka-zarez (;), ono što se nalazi ispred toga Andriotisov je navod, izuzev prijevoda na hrvatski jezik.

13 https://www.etymonline.com/word/omnibus\#etymonline_v_7004 (8. I. 2021.)

14 https://www.etymonline.com/word/realism\#etymonline_v_7330 (8. I. 2021.)

15 https://www.etymonline.com/word/materialism\#etymonline_v_31150 (8. I. 2021.)

16 https://www.britannica.com/topic/humanism (8. I. 2021.) 


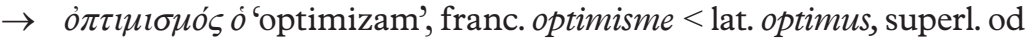
bonus

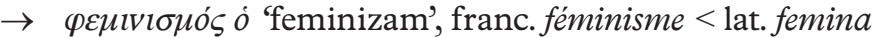

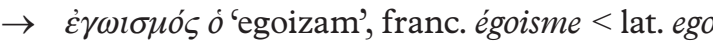

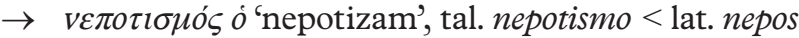

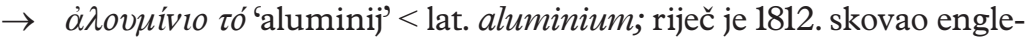
ski kemičar Sir Humphry Davy prema latinskom alumen, -inis, $n$. 'stipsa, alaun' ${ }^{17}$

$\rightarrow \chi \lambda \omega$ ó

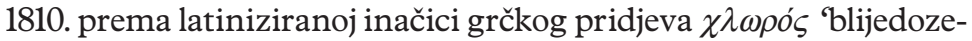
len, žutozelen ${ }^{18}$

$\rightarrow$ ov̉ox́vio tó 'uran' < lat. uranium; riječ skovao njemački kemičar i mineralog Martin Heinrich Klaproth 1789. prema latinskom uranus 'nebo', odnosno grč. ovjpavós ${ }^{19}$

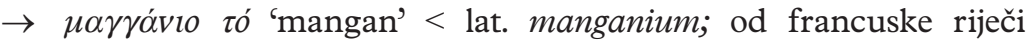
manganèse (XVI. st.), prema talijanskom manganese, što je alteracija ili iskrivljenost srednjovjekovne latinske riječi magnesia ${ }^{20}$

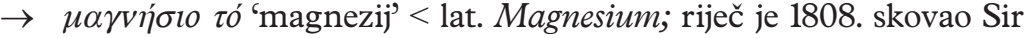
Humphry Davy prema lat. magnesia ‘živa, živo srebro', što je ustvari preuzeto iz starogrčkog $\dot{\eta} \mu \alpha \gamma v \tilde{\eta} \tau ı \varsigma \lambda i \theta o \varsigma$ 'magnezijski, magnetski kamen', mineral za koji se smatra da je pronađen u Magneziji, u grčkoj regiji Tesaliji, koja je dobila ime prema Magnećanima. ${ }^{21}$

2. U nekim slučajevima Andriotis navodi da je riječ preuzeta iz latinskog, no prema drugim izvorima možemo utvrditi da je riječ postojala još u starogrčkome te su neke od njih vjerojatno povratne ili izravne posuđenice iz starogrčkog:

\footnotetext{
17 https://www.etymonline.com/word/aluminum\#etymonline_v_10934 (8. I. 2021.)

$18 \mathrm{https} / /$ www.etymonline.com/word/chlorine\#etymonline_v_11296 (8. I. 2021.)

19 https://www.etymonline.com/word/uranium\#etymonline_v_4556 (8. I. 2021.)

20 https://www.etymonline.com/word/manganese\#etymonline_v_6789 (8. I. 2021.)

${ }^{21} \mathrm{https} / / / \mathrm{www} . e t y m o n l i n e . c o m / w o r d / m a g n e s i a \#$ etymonline_v_2190 (8. I. 2021.)
} 


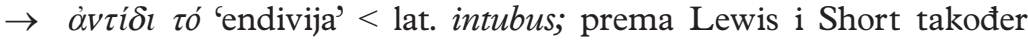
intǐbus (intybus) ili intǐbum (intybum) od grčkog ěv $\tau v \beta o v$, što znači da se radi o povratnoj posuđenici ${ }^{22}$

$\rightarrow \lambda \varepsilon о \pi \alpha ́ \rho \delta \alpha \lambda \eta \dot{\eta}^{\prime}$ leopard'< lat. leopardus; vjerojatnija etimologija prema riječi leopardalis koja potječe od grčkog $\lambda \varepsilon \dot{\varepsilon} \omega v$ et $\pi \alpha ́ \rho \delta \alpha \lambda \iota \varsigma$, što ju čini povratnom posuđenicom

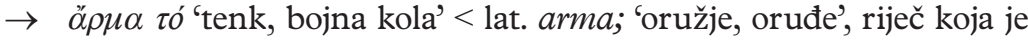
posvjedočena još kod Homera u obliku ö $\rho \mu \alpha, \alpha \tau o \varsigma, \tau o ́ ~ ' k o l a '$

$\rightarrow$ фópos $\dot{o}$ 'porez' < lat. forum; 'trg, tržište', ova se riječ u istome obliku pojavljuje još kod Herodota ('danak, carina, porez'), a također je vidljiv prijevoj kod glagola $\varphi \varepsilon ́ \rho \omega$

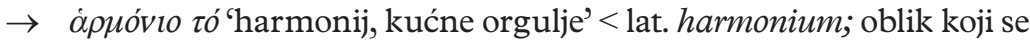
pojavljuje u ženskome rodu harmonia, -ae, $f$. 'sloga', a zapravo se radi o riječi starogrčkog porijekla á $\rho \mu o v i ́ \alpha(\alpha \rho \mu o ́ \zeta \omega)$ 'spajanje, sklad, harmonija'. Kasnije nailazimo na sljedeći navod: $\dot{\alpha} \rho \operatorname{cov} \kappa \alpha \dot{\eta}$

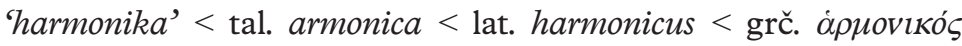
'skladan', gdje vidimo kako Andriotis prepoznaje starogrčki korijen riječi, no ne ostaje dosljedan u svojem navodu

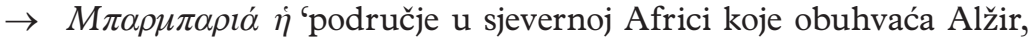
Maroko i Tunis' < lat. Barbaria; 'negrčka, nerimska, tuđinstvo',

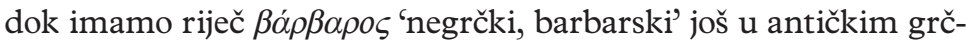
kim djelima koja se pojavljuje kao 312. najčešća starogrčka riječ ${ }^{23}$

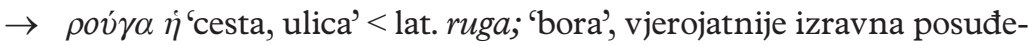
nica od starogrčkog $\rho \dot{u} \mu \eta, \dot{\eta}$ 'cesta'.

3. U nekim slučajevima Andriotis navodi oblike koji u latinskome nisu posvjedočeni:

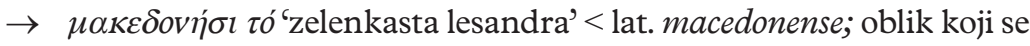
ne pojavljuje u latinskom jeziku, možda od macedonicus

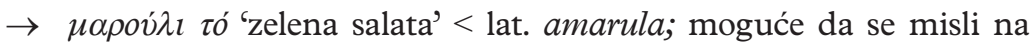
pridjev amarus ili amarulentus 'gorak'

$\rightarrow \mu \pi о \tilde{v} \varphi о \varsigma \dot{o}$ 'sova' < lat. bufus; uzmemo li u obzir zamjenu glasova b i $\mathrm{f}^{24}$ dolazimo do mogućega rješenja: bubo, -onis, $m$. 'sova'; Strix bubo

${ }^{22}$ https://logeion.uchicago.edu/intibus (8. I. 2021.)

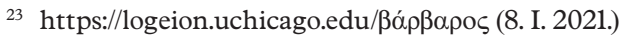

$24 » I n t e r v o k a l n o / b /$ je okluziv i prelazi u spirant« (Tekavčić 1970: 112). 


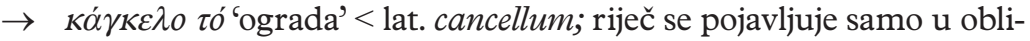
ku muškog roda cancellus, $-i, m$. 'ograda, granica'

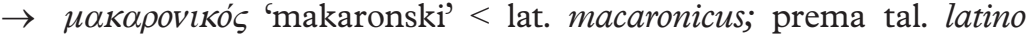
maccheronico 'iskvareni, kuhinjski' latinski. Termin je 1517. skovao Teofilo Folengo, koji je popularizirao taj stil u Italiji, no riječ nije posvjedočena u latinskom jeziku ${ }^{25}$

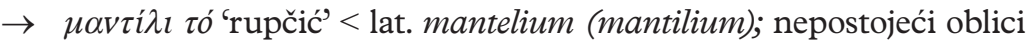
u rječnicima latinskoga jezika, vjerojatno od mantelum 'plašt, ogrtač'

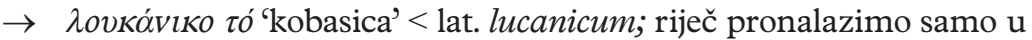
obliku ženskoga roda lucanica 'vrsta kobasica mešnjača'

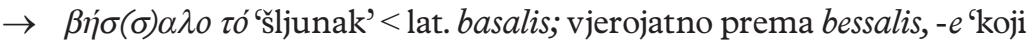
sadržava osam nečega'; metonimijski za bilo što male vrijednosti

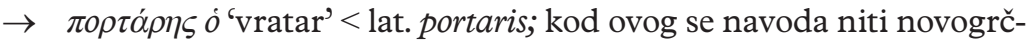

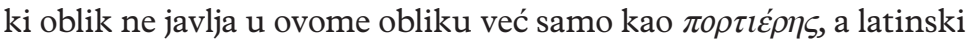
u obliku portarius

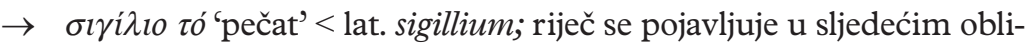
cima: sigilla, -orum, $n$. 'pečat', sigillum, $n$. te sigilliolum, $n$. u istom značenju, međutim, oblik sigillium nije posvjedočen

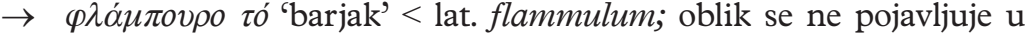
srednjem rodu nego u ženskom: flammula 'plamičak; mala zastava'.

4. Kod nekih riječi Andriotis navodi krivo podrijetlo:

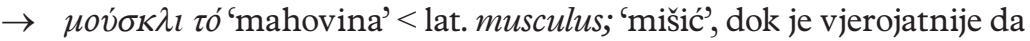
riječ dolazi od latinske imenice muscus ili muscum 'mahovina'

$\rightarrow$ коv́ $\beta \alpha$ i' prostitutka' < lat. curva; 'kriv, iskrivljen', međutim, ovdje je izglednije da se radi o posuđenici iz slavenskih jezika (Agostini 1986: 375).

5. Također, u Rječniku se može pronaći određen broj riječi koje ne postoje u standardnim rječnicima novogrčkoga jezika. To se ne odnosi isključivo na latinizme, ali ih se tiče i dodatno otežava istraživanje. Tomu je moguć razlog to što je Andriotis bilježio arhaizme i dijalektizme:

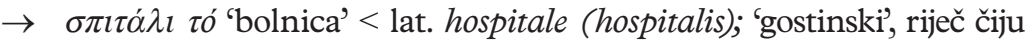
prvu zabilješku pronalazimo već u XIV. st. u srednjovjekovnom djelu

25 https://enciklopedija.hr/Natuknica.aspx?ID=38238 (8. I. 2021.) 
Morejska kronika. Zatim ju pronalazimo u stihu autora Dimitrija Skarlata iz XIX. st., nakon čega nestaje iz uporabe te je danas samo toponim na Peloponezu iCipru; moderna riječ za bolnicu je voбoкo

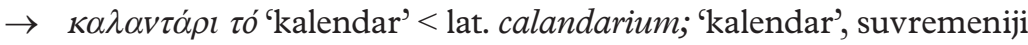
je sinonim $\eta \mu \varepsilon \rho o \lambda o ́ \gamma t o$

$\rightarrow \beta \varepsilon ́ v \alpha$ i'vena, žila' < lat. vena; 'žila' riječ karakteristična za govorno područje otoka Lefkade ili možda još nekog od otoka u jonskom arhipelagu, no u standardnome jeziku glasi $\varphi \lambda \dot{\varepsilon} \beta \alpha$

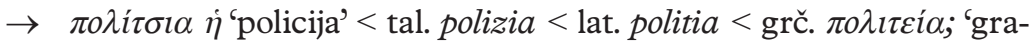
đansko pravo, politika, vlada', povratna posuđenica iz starogrčkog koja je naposljetku u novogrčki došla iz talijanskog jezika. Standardna riječ za isti pojam je $\alpha \sigma \tau v v o \mu i ́ \alpha$

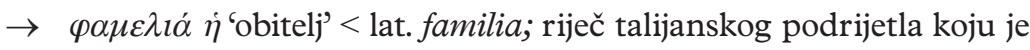
tijekom čišćenja grčkoga jezika od tuđica u XIX. st. zamijenila grč-

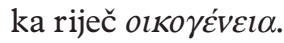

Andriotis dakle u nekim slučajevima izostavlja bitne etimološke informacije o prijelazu latinskih riječi u novogrčki, ne navodeći jezik posrednik. U drugim pak slučajevima za pojmove sličnih karakteristika to radi te time pokazuje nedosljednost $\mathrm{u}$ obradi podataka. Ponekad donosi netočne navode, tvrdeći da je određena riječ latinizam, a vjerojatnije je da je povratna posuđenica iz starogrčkoga ili je pak bez ikakva posredništva latinskoga jezika pristigla u novogrčki. Nadalje, pronađeni su navodi u kojima autor bilježi oblike koji kao takvi u latinskome nisu posvjedočeni, ili pak navodi krivo podrijetlo. Naposljetku, autor je u svoj rječnik uključio velik broj natuknica koje ne pripadaju leksiku standardnoga novogrčkoga jezika.

\section{Zaključak}

Andriotisov je Rječnik iz nekoliko razloga vrlo važan za grčku leksikografiju. On predstavlja značajan izvor informacija o povijesti i razvoju grčkoga jezika, tim više što ga pronalazimo u tri različita izdanja s po 16 godina razmaka između prvoga i drugoga te drugoga i trećega izdanja. Nadalje, to je prvi etimološki rječnik novogrčkoga jezika koji se pojavljuje na grčkome tržištu te samim time budućim leksikografima, s naumom stvaranja rječnika te vrste, postavlja ljestvicu i služi kao svojevrstan ogledni primjerak. Što se pak latinizama tiče, Andriotis (1983) i sam napominje da se autor etimološkoga rječnika, kako u sadašnjosti tako i u budućnosti, nalazi u nepovoljnoj situaciji, gdje mora birati između onoga što je vjerojatno, nesigurno ili nepoznato. Andriotis je grecist, no ne i latinist, te je stoga njegova obrada latinizama često manjkava. Međutim, kao što su to neki drugi jezičari već ranije napomenuli, Rječnik 
bi se morao pročistiti od znatnoga broja natuknica, a velik broj natuknica koje se u njemu nalaze s opravdanim razlogom trebao bi biti prepravljen.

Kao što smo ranije napomenuli, Andriotisove se greške i propusti mogu svrstati u nekoliko skupina: ispuštanje posredničkoga jezika u navođenju latinizama u novogrčkom, netočni navodi, odnosno navodi prema kojima je određena riječ latinizam, iako postoje dokazi prisutnosti iste već u starogrčkom jeziku, navođenje neposvjedočenih oblika u latinskome, navođenje krivoga podrijetla riječi te naposljetku korištenje određenih dijalektizama i arhaizama kojima nije mjesto u rječniku standardnoga novogrčkoga jezika bilo koje vrste. Zaključno, Andriotisov je Rječnik vrijedan izvor građe za sve one koji se bave grčkim jezikom i zanimaju za etimologiju njegova leksika, no određene bi natuknice trebale biti revidirane u budućim izdanjima. 


\section{LITERATURA}

Adams, James Noel, Janse, Mark i Swain, Simon (ur.) (2002). Bilingualism in Ancient Society. Oxford University Press.

Agostini, Paolo (1986). »Una parola balkanica e la sua etimologia: kurva«. Balkan Studies, 27(2), 369-375.

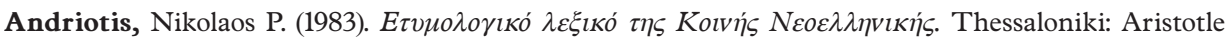
University.

Babiniotis, Georgios (2002). Leksiko tis Neas Ellinikis glossas [Dictionary of Modern Greek language]. Atena: Kentro Lexikologias.

Clackson, James, Horrocks, Geoffrey (2011). The Blackwell history of the Latin language. Oxford: Wiley-Blackwell.

Divković, Mirko (1997). Latinsko-hrvatski rječnik za škole. 8. izdanje. Zagreb: Naprijed.

Filos, Panagiotis (2013). »Latin Loanwords in Greek«. U: Encyclopedia of Ancient Greek Language and Linguistics, str. 320-323. Leiden-Boston.

Georgakas, Dimitrios Ioannis (1958). »Remarks on Andriotis' Etymological lexicon«. Byzantinische Zeitschrift, 51(1), 43-52.

Homer (1987). Odiseja. Preveo i protumačio Tomo Maretić, Nakladni zavod Matice hrvatske, Zagreb.

Horrocks, Geoffrey (2010). Greek: a history of language and its speakers. London-New York: Longmans.

Kahane, Renée (1982). »The western impact on Byzantium: the linguistic evidence«. Dumbarton Oaks Papers, 36, 127-153.

Lavidas, Nikolaos (2018). »Language change and early dictionaries of Modern Greek«. U: Studies in Greek Lexicography 57-78. Berlin: De Gruyter.

Lončar, Alka (2020). »Latinske posuđenice u novogrčkom jeziku«. Diplomski rad, Sveučilište u Zagrebu.

Mackridge, Peter (2009). »A language in the image of the nation: Modern Greek and some parallel cases«. U: The making of modern Greece: nationalism, romanticism, and the uses of the past (17971896), 177-188.

Mackridge, Peter (2014). »The Greek language since 1750«. U: Storia e storie della lingua greca, 133-164. Venice: Edizioni Ca' Foscari.

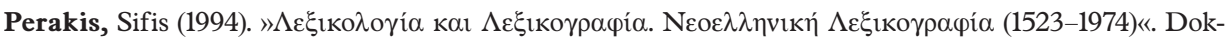
torska disertacija. Sveučilište u Ateni.

Sihler, Andrew L. (2008). New comparative grammar of Greek and Latin. Oxford University Press.

Senc, Stjepan (1991). Grčko-hrvatski rječnik za škole. 3. izdanje. Zagreb: Naprijed.

Tekavčić, Pavao (1970). Uvod u vulgarni latinitet, s izborom tekstova. Zagreb: Sveučilište Zagreb. 


\title{
MREŽNI IZVORI
}

Humanism, Britanica, https://www.britannica.com/topic/humanism (8. I. 2021.)

Aluminium, Etymonline, https://www.etymonline.com/word/aluminum\#etymonline_v_10934 (8. I. 2021.)

Chlorine, Etymonline, https://www.etymonline.com/word/chlorine\#etymonline_v_11296 (8. I. 2021.)

Magnesia, Etymonline, https://www.etymonline.com/word/magnesia\#etymonline_v_2190 (8. I. 2021.)

Manganese, Etymonline, https://www.etymonline.com/word/manganese\#etymonline_v_6789 (8. I. 2021.)

Materialism, Etymonline, https://www.etymonline.com/word/materialism\#etymonline_v_31150 (8. I. 2021.)

Omnibus, Etymonline, https://www.etymonline.com/word/omnibus\#etymonline_v_7004 (8. I. 2021.)

Realism, Etymonline, https://www.etymonline.com/word/realism\#etymonline_v_7330 (8. I. 2021.)

Uranium, Etymonline, https://www.etymonline.com/word/uranium\#etymonline_v_4556 (8. I. 2021.)

makaronsko pjesništvo. Hrvatska enciklopedija, mrežno izdanje. Leksikografski zavod Miroslav Krleža, 2021. $<$ http://www.enciklopedija.hr/Natuknica.aspx?ID $=38238>$ (10. I. 2021.)

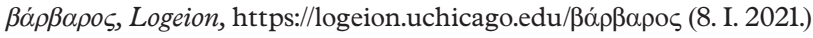

Intibus, Logeion, https://logeion.uchicago.edu/intibus (8. I. 2021.)

\section{THE PROBLEMS IN ANALYSIS OF LATIN LOANWORDS IN NIKOLAOS ANDRIOTIS' ETYMOLOGICAL DICTIONARY OF MODERN GREEK}

\author{
Alka Lončar \\ Roma Tre University, Rome \\ alk.loncar@stud.uniroma3.it
}

ABSTRACT: It is well known that Greek language and culture had a great impact on Roman culture and literature in the Latin language. However, the influence of the Latin language on Greek has drawn less attention, particularly when it comes to loanwords. The goal of this paper is to show the difficulties and certain unfounded claims in the course of analysis of Latinisms observed during the research on the Etymological Dictionary of Modern Greek by linguist and lexicographer Nikolaos Andriotis.

Keywords: etymology; language contact; language borrowing; Latin; modern Greek 